\title{
Redox-active labile iron in fortified flours from the Brazilian market
}

\author{
Ferro lábil redox-ativo em farinhas fortificadas \\ do mercado brasileiro
}

Breno Pannia ESPÓSITO'

A B S T R A C T

\section{Objective}

To quantify the fraction of redox-active labile iron in iron-fortified flours acquired on the Brazilian market.

\section{Methods}

Samples of wheat flour, maize flour and breadcrumbs were extracted with buffers that mimic gastric juice, saliva and intestinal juice. Redox-active labile iron levels were assessed through the reaction of autoxidation of ascorbic acid catalyzed by iron in the presence of a fluorescence probe.

\section{Results}

Redox-active labile iron represents $1 \%$ to $9 \%$ of the total iron in the flour and breadcrumb samples, with the lowest values found under gastric juice conditions and the highest in the more alkaline media. Redox-active labile iron possibly arises from the decomposition of an iron-phytic acid complex. A positive correlation between redox-active labile iron and total iron was found in saline biomimetic fluids.

\section{Conclusion}

Redox-active labile iron may be a risk factor for people with impaired antioxidant defenses, such as those who are atransferrinemic or iron overloaded (e.g. thalassemic). Total iron can be used to predict redox-active labile iron absorption at each stage of the gastrointestinal tract after ingestion of iron-fortified flours.

Indexing terms: Brazil; flour; fluorescence; iron; redox activity.

\section{RES U M O}

\section{Objetivo}

Quantificar a porcentagem de ferro lábil redox ativo em farinhas fortificadas adquiridas no comércio popular.

1 Universidade de São Paulo, Instituto de Química. Av. Lineu Prestes 748, sala 1265, 05508-000, São Paulo, SP, Brasil. E-mail: <breno@iq.usp.br>. 


\section{Métodos}

Amostras de farinha de trigo, fubá e rosca foram extraídas com tampões miméticos de suco gástrico, saliva e suco intestinal. Os níveis de ferro lábil redox ativo foram determinados por meio da reação de auto-oxidação do ácido ascórbico catalisada pelo ferro, em presença de uma sonda fluorimétrica.

\section{Resultados}

A fração de ferro lábil redox ativo representa entre 1\% e 9\% do ferro total nas farinhas estudadas, sendo os menores valores encontrados em condições miméticas do suco gástrico e os maiores nos meios mais alcalinos. Há indícios de que o ferro lábil redox ativo origina-se da decomposição de um complexo entre ferro e ácido fítico. Observa-se uma correlação positiva entre ferro lábil redox ativo e ferro total nas condições de salinidade dos fluidos biomiméticos estudados.

\section{Conclusão}

Ferro lábil redox ativo pode ser um fator de risco para pacientes atransferrinêmicos, sistemicamente sobrecarregados com ferro (por exemplo, talassêmicos) ou aqueles com defesas antioxidantes comprometidas por enfermidades. A quantidade de ferro total pode ser preditiva dos níveis de ferro lábil redox ativo absorvidos em cada etapa do trato gastrintestinal após a ingestão de farinhas fortificadas.

Termos de indexação: Brasil; farinha; fluorescência; ferro; redox atividade.

\section{NTRODUCTION}

Iron deficiency anemia is one of the main nutritional disorders today, affecting approximately $37 \%$ of the world's population ${ }^{1}$. Although there are no official statistics in Brazil, regional studies point towards a significant increase in the prevalence of this deficiency in risk groups in recent decades, with $50 \%-83 \%$ of infants up to two years of age being considered anemic ${ }^{2}$. As in other developing nations, there is enough evidence to associate the iron status of the Brazilian population, irrespective of social class, with the relatively low bioavailable iron content of the major ingredients of the national diet (based mostly on grains and vegetables) $)^{2,3}$.

Iron fortification of food is a cost-effective approach to providing iron for the population ${ }^{4}$. Fortificants differ markedly in chemical identity, bioavailability, likelihood of causing adverse sensory changes, advantages and usage restrictions. Thus, the food vehicle, food packaging and target population are very important factors to consider when choosing a specific iron compound and absorption enhancers.

After similar efforts throughout the world, Brazil started fortifying maize and wheat flours with $4.2 \mathrm{mg}$ of Fe per $100 \mathrm{~g}$ of flour in $2002^{5}$. Approved additives include ferrous sulfate, ferrous fumarate, reduced iron, electrolytic iron, sodium iron EDTA and ferrous bisglycinate. The cost of this operation, as demonstrated previously ${ }^{6}$, is negligible. Today it costs less than US $\$ 0.02$ to fortify $100 \mathrm{~kg}$ of flour with ferrous sulfate?

Although this approach has proved successful in decreasing iron deficiency worldwide ${ }^{4,8}$, a number of studies have addressed the potential long-term side effects associated with the regular ingestion of highly bioavailable iron forms in food, at least for some segments of the population ${ }^{8}$. A basic assumption is that food fortificants might induce transient but systematic iron overload episodes which may be, at the onset of several clinical conditions, in part due to the propensity of iron to integrate physiological pools of weakly bound forms with potential pro-oxidant activity. In blood, these forms have been collectively termed labile plasma iron (LPI) ${ }^{9}$ and defined as a heterogeneous fraction of iron associated with albumin and/or low molecular weight ligands such as citrate, hormones and amino acids. Interestingly, part of LPI has been shown to catalyze the autoxidation of ascorbic acid in vitro and in plasma samples at physiological ascorbate levels $\mathrm{s}^{9,10}$. Ascorbic acid is one of the most promising enhancers of dietary iron absorption ${ }^{11}$. The pro-oxidant deleterious activity of the iron-ascorbate mixture both in food matrices ${ }^{12,13}$ and in experimental animal 
models ${ }^{14-18}$ has been previously reported, although its relevance to daily meals is still elusive.

In this study, a fluorescence-based method was employed to quantify the redox-active, labile iron (RALI) in extracts of iron-enriched flours available in Brazilian supermarkets.

\section{METHODS}

The following reagents were used without further purification unless otherwise noted: ferrous ammonium sulfate (FAS), reduced iron $\left(\mathrm{Fe}^{0}\right)$, ascorbic acid, nitrilotriacetic acid (Cromoline, Diadema, Brazil); 1,2,3-dihydrorhodamine dihydrochloride (DHR; Biotium, Hayward, USA); deferiprone (L1; Apotex, Toronto, Canada); HEPES (N-2-hydroxy-ethylpiperazine- $N$ '-2-ethanesulfonic acid), Chelex-100 (Sigma, St. Louis, USA). Ironfree HBS (HEPES $20 \mathrm{mM}, \mathrm{NaCl} 150 \mathrm{mM}, \mathrm{pH} 7.4$ ) was obtained by treatment with $1 \mathrm{~g} .100 \mathrm{~mL}^{-1}$ Chelex-100 resin.

Samples of fine ( 2 brands) or coarse (4 brands) maize flours, wheat flour ( 6 brands), tapioca flour (4 brands) and breadcrumbs (3 brands) were acquired in a supermarket (city of São Paulo, São Paulo state, Brazil) and used without processing.

\section{Flour extraction}

Artificial gastric juice $(\mathrm{pH} 1.2)$, saliva $(\mathrm{pH}$ 6.5) and intestinal juice $(\mathrm{pH}$ 6.8) were prepared as described ${ }^{19}$. Samples of ca. $1 \mathrm{~g}$ of flour were treated with $5.0 \mathrm{~mL}$ of each extractant or $5.0 \mathrm{~mL}$ Milli-Q water (blanks) in plastic tubes and shaken at $130 \mathrm{xg}$ at $37^{\circ} \mathrm{C}$ for 30 minutes in a Tecnal TE-421 incubator (Tecnal, Piracicaba, Brazil). Approximately $1.0 \mathrm{~mL}$ of each suspension was transferred to plastic vials and centrifuged at $11300 \mathrm{xg}$ for 5 minutes. The supernatants were collected and kept in a refrigerator.

\section{Redox-active Fe assay}

The detailed protocol and its rationale have been described elsewhere ${ }^{9}$. In brief, quadruplicates of $20 \mu \mathrm{L}$ aliquots of the extracts were transferred to clear-bottom, 96-well plates (TPP, Trasadingen, Switzerland). Two of the replicates were treated with $40 \mu \mathrm{M}$ ascorbate and $50 \mu \mathrm{M}$ DHR in iron-free HBS. The other two received the same treatment plus $100 \mu \mathrm{M}$ deferiprone (L1). Standard Fe samples were prepared by the dilution of stock solutions of nitrilotriacetate:FAS (10:1 molar ratio) in the same solvents used for extraction and treated as the unknown samples. Fluorescence was recorded for 40 minutes at $37^{\circ} \mathrm{C}$ using a Tecan Genios microplate reader (Tecan, Mannendorf, Switzerland) with a 485/535 nm excitation/emission filter pair. The slopes ( $r$ ) of DHR fluorescence curves against time were calculated from measurements taken between 15 and 40 minutes. Calibration curves were constructed by plotting the difference $\left(r_{\text {noL1 }}\right.$ $\left.r_{\text {plus L1 } 1}\right)$ against Fe concentration. The detection limit for iron is $2 \mu \mathrm{M}$. Analysis of variance (ANOVA, $p<0.05)$ followed by group comparison with Fisher's LSD (Protected t-Test) were performed with GBSTAT ${ }^{\circledR}$ software (version 9.0; Dynamic Microsystems).

\section{Total Fe content}

One gram of each sample was accurately weighed and treated with $10 \mathrm{~mL}$ of concentrated $\mathrm{HNO}_{3}$ in a beaker covered with a glass plate. The reaction was allowed to proceed for $5 \mathrm{~h}$ at $100^{\circ} \mathrm{C}$ over an electric plate. Two $\mathrm{mL}$ of $\mathrm{H}_{2} \mathrm{O}_{2}(30 \%)$ were added and the solution was refluxed for $1 \mathrm{~h}$ at the same temperature. Finally, $2 \mathrm{~mL}$ of concentrated $\mathrm{HCl}$ were added and, after 2 hours, the reflux was stopped. After cooling to room temperature, the acid extract was filtered to a $50 \mathrm{~mL}$ volumetric flask and the final volume was adjusted. Triplicates were analyzed in a Spectro CIROS-CCD ICP-AES (Spectro Analytical Instruments, Kleve, Germany) spectrometer.

\section{RESULTS AND DISCUSSION}

Coarse maize flour (4 brands), tapioca flour (4 brands) and finely crushed breadcrumbs ( 2 brands) had no detectable amount of RALI. Since 
these flours and breadcrumbs are not legally subjected to iron fortification, they where excluded from further studies.

The producers of each brand were personally contacted for information on the exact nature of the iron fortificant applied in the specific batches acquired for this study. All the flours were fortified with reduced iron (325 Tyler Mesh). Currently, this is the only iron fortificant used by Brazilian flour industries, for reasons that include low cost, ease of homogenization, lack of hygroscopic properties and absence of visual effects (e.g., brown spots in wheat flour are often observed due to oxidation of $\mathrm{FeSO}_{4}$ ).

The total iron content of all the flour and breadcrumb samples was above the minimum required by law (Table 1; mean: $6.0 \mathrm{mg} / 100 \mathrm{~g}^{-1}$; required: $\left.4.2 \mathrm{mg} / 100 \mathrm{~g}^{-1}\right)$.

Total iron and RALI values for maize flour, wheat flour and breadcrumbs are shown in Table 1. The breadcrumbs brand in which RALI was found to be present had iron-fortified wheat flour in its preparation (according to the producer).

The strongly acidic solutions generated low concentrations of RALI. When observed, they were always significantly lower $(p<0.05)$ than the RALI concentrations generated in intestinal juice. This result could be explained by $\mathrm{pH}$ effects on the fluorescence signal in the assay, since it is known that low pH values may decrease the quantum yield of a fluorescence probe ${ }^{20}$ under steady conditions, resulting in a bias towards low values when solutions such as gastric juice are used. However, the advantage of this method is that a kinetic curve of the fluorescence is constructed, so that curve slopes rather than end-point measurements are used to assess iron concentrations $^{9}$. Prior to the experiments, the slopes of the fluorescence curves were not affected by the $\mathrm{pH}$ of the medium (data not shown).

Therefore, the reason for the low RALI concentrations in gastric juice must be sought elsewhere. Stable iron complexes such as Fe(EDTA) show optimum formation under very acidic conditions. Iron thus effectively competes with $\mathrm{H}_{3} \mathrm{O}^{+}$for the ligand-binding sites at low $\mathrm{pH}$, but with increasing alkalinity it tends to be mobilized from the complex due to the formation of stable polymeric (hydr)oxides (in the extreme case $^{21}$, solid $\left.\mathrm{Fe}(\mathrm{OH})_{3} ; K_{\mathrm{sp}}=2.0 \times 10^{-39}\right)$. This is the thermodynamic reason underlying previous observations that the absorption of iron fortificants is prevented in the stomach and favored in the more alkaline environment of the duodenum ${ }^{22}$. Among the natural chelating agents present in flours, phytic acid (PA; myoinositol-6-phosphate) is the most prominent, forming very stable

Table 1. Redox-Active Labile Iron (RALI) and total iron in flours and breadcrumbs from different sources.

\begin{tabular}{|c|c|c|c|c|c|c|c|c|c|c|}
\hline & \multicolumn{8}{|c|}{ RALI $(p p m)^{a}$} & & \\
\hline & \multicolumn{2}{|c|}{1} & \multicolumn{2}{|c|}{$S$} & \multicolumn{2}{|c|}{ G } & \multicolumn{2}{|c|}{ W } & \multicolumn{2}{|c|}{ Total Fe $(p p m)^{\mathbf{a}}$} \\
\hline & $M$ & SD & $M$ & SD & $M$ & SD & M & SD & $M$ & SD \\
\hline Maize 1 & 2.44 & 0.15 & 1.68 & 0.12 & \multicolumn{2}{|c|}{ nd } & \multicolumn{2}{|c|}{ nd } & 46.65 & 0.93 \\
\hline Maize 2 & 1.61 & 0.07 & 0.78 & 0.29 & \multicolumn{2}{|c|}{ nd } & \multicolumn{2}{|c|}{ nd } & 46.61 & 1.43 \\
\hline Breadcrumbs & 3.59 & $0.15^{*}$ & 2.69 & 0.24 & 2.40 & 0.57 & 2.36 & 0.05 & 81.71 & 0.01 \\
\hline Wheat 1 & 4.49 & $0.29^{*}$ & 4.08 & $1.12^{*}$ & 1.69 & 0.35 & 4.64 & $0.23^{*}$ & 52.87 & 0.04 \\
\hline Wheat 2 & 3.68 & $0.28^{*}$ & 2.44 & 0.37 & 2.01 & 0.01 & 3.36 & $0.43^{*}$ & 65.32 & 0.57 \\
\hline Wheat 3 & 3.42 & $0.09 *$ & 3.31 & $0.25^{*}$ & 2.16 & 0.10 & 2.45 & 0.06 & 76.63 & 0.12 \\
\hline Wheat 4 & 1.82 & 0.12 & 1.62 & 0.83 & \multicolumn{2}{|c|}{ nd } & 0.82 & 0.14 & 66.09 & 0.42 \\
\hline Wheat 5 & 2.89 & 0.87 & 1.48 & 1.01 & \multicolumn{2}{|c|}{ nd } & 3.39 & 0.46 & 52.28 & 0.17 \\
\hline Wheat 6 & 2.09 & 0.47 & 1.91 & 0.65 & \multicolumn{2}{|c|}{ nd } & 2.04 & 0.24 & 53.91 & 1.24 \\
\hline
\end{tabular}

a Results are expressed as means and standard deviation - SD (n:2 for RALI and n:3 for Total Fe).

Asterisks ${ }^{*}$ ) indicate significant differences from gastric juice according to analysis of variance (ANOVA, $p<0.05$ ) and comparison of the groups by Fisher's LSD (Protected t-Test).

nd: not detectable. I: artificial intestinal juice; S: artificial saliva; G: artificial gastric juice; W: water. 
complexes $^{23}$ with iron $\left(K_{\mathrm{ML}} \sim 10^{25}-10^{30}\right)$. Not surprisingly, PA is the major inhibitor of iron absorption from cereals, where it is present in the considerable amounts of $1 \%-6 \%$ on a weight basis $^{24-26}$. PA also renders iron non-redox-active even in the presence of ascorbic acid, suggesting its possible role as an antioxidant agent ${ }^{27}$. In order to gain some insight into the effect of $\mathrm{pH}$ on the stability of Fe-PA complexes, computer simulations with CHEAQS software ${ }^{28}$ were performed adopting the $\mathrm{p} K_{\mathrm{a}}$ values for PA derived from ${ }^{31} \mathrm{P}-\mathrm{NMR}$ measurements ${ }^{29}$ and the equilibrium constant ${ }^{23}$ $\log K_{\mathrm{ML}}$ of 25 for the $\mathrm{Fe}(\mathrm{PA})_{3}$ complex formation. For simplicity, only the first deprotonation of PA was considered in the calculations (Table 2). At acidic $\mathrm{pH}$, only the complex $\mathrm{Fe}(\mathrm{PA})_{3}$ is stable in solution, but approximately $16 \%$ of the iron is mobilized to other less stable forms at $\mathrm{pH} 7$. The fact that RALI is observed in some cases at $\mathrm{pH}=1.2$ indicates that more complete databases (e.g. allowing for each of the twelve PA protonation events, different Fe:PA stoichiometries or variable ionic strengths) are required to properly calculate the equilibrium values. Thus, both experimental and simulated results suggest that RALI originates from the dissociation of a $\mathrm{Fe}^{3+}$-PA complex formed in the flour during its extraction.

The protective effect of PA against polymerization of iron (hydr)oxo compounds can be observed when it is removed from the computation. As expected, even at pH 2 most of the metal is precipitated as oxide, and there are virtually no soluble iron species at $\mathrm{pH} 7$.
A positive correlation between RALI and total iron in the flours was observed for the mimetic biological extractants but not for ultra-pure water (Figure 1). This indicates that total iron values can be used to predict the amount of redox-active metal mobilized at each stage of the gastrointestinal tract. Importantly, the results show that it is possible to determine the concentration of RALI formed in the small intestine, where dietary Fe absorption occurs ${ }^{30}$. In agreement with the above discussion, the formation of RALI in gastric juice is observed only at relatively high (>50ppm) total iron contents.

The absence of a linear correlation between RALI and total iron in pure water may be explained by considering the chemical nature of the fortificant (reduced iron). It may be assumed that any factors which favor the $\mathrm{Fe}^{0}$ to $\mathrm{Fe}^{3+}$ conversion are operative during the extraction procedure. Iron corrosion in aqueous medium is known to depend on the oxygen concentration - which was the same for all extractants, since all the extractants were prepared with ultra-pure water - but also to be greatly accelerated by increased ionic strength ${ }^{21}$. Accordingly, we found that only the high salinity extractants mobilized iron in a predictable manner.

From the data in Table 1, it was found that ca. $1-9 \%$ of the total iron in the flour and breadcrumb samples is labile and redox-active when in the presence of physiological concentrations of ascorbic acid under the experimental conditions. These values are comparable to the $2-6 \%$ low molecular weight and redox-active iron found in parenteral iron supplements ${ }^{10}$. The relevance of

Table 2. CHEAQS PRO** simulation ( $I=0)$ of $\mathrm{pH}$ and phytic acid $(\mathrm{PA})$ concentration effects on iron speciation $(2 \mu \mathrm{M})$.

\begin{tabular}{|c|c|c|c|c|c|c|}
\hline \multirow[b]{3}{*}{ Soluble species $(\%)^{*}$} & \multicolumn{3}{|c|}{$\mathrm{pH}=2.0$} & \multicolumn{3}{|c|}{$\mathrm{pH}=7.0$} \\
\hline & \multicolumn{2}{|l|}{$P A=0$} & \multirow[t]{2}{*}{$\mathrm{PA}=10 \mu \mathrm{M}$} & \multirow[t]{2}{*}{$P A=0$} & \multicolumn{2}{|c|}{$\mathrm{PA}=10 \mu \mathrm{M}$} \\
\hline & {$\left[\mathrm{Fe}(\mathrm{H} 2 \mathrm{O})_{6}\right]^{3+}$} & (19.75) & & & {$\left[\mathrm{Fe}(\mathrm{OH})_{2}\right]^{+}$} & ( 2.14) \\
\hline & {$[\mathrm{Fe}(\mathrm{OH})]^{2+}$} & ( 8.68) & $\mathrm{Fe}(\mathrm{PA})_{3}(100)$ & none & {$\left[\mathrm{Fe}(\mathrm{OH})_{4}\right]^{-}$} & (13.59) \\
\hline & {$\left[\mathrm{Fe}(\mathrm{OH})_{2}\right]^{+}$} & $(0.27)$ & & & $\mathrm{Fe}(\mathrm{OH})_{3} \mathrm{aq}$ & $(0.02)$ \\
\hline & & & & & $\mathrm{Fe}(\mathrm{PA})_{3}$ & (84.25) \\
\hline Insoluble species (\%)* & $\mathrm{Fe}_{2} \mathrm{O}_{3}$ & (71.30) & none & $\mathrm{Fe}_{2} \mathrm{O}_{3} \quad(100)$ & \multicolumn{2}{|c|}{ none } \\
\hline
\end{tabular}

*Percent of total Fe concentration. aq: aqueous; **Verweig W. CHEAQS PRO [computer program] $]^{28}$. 
Artificial Intestinal Juice $(R=0.822)$

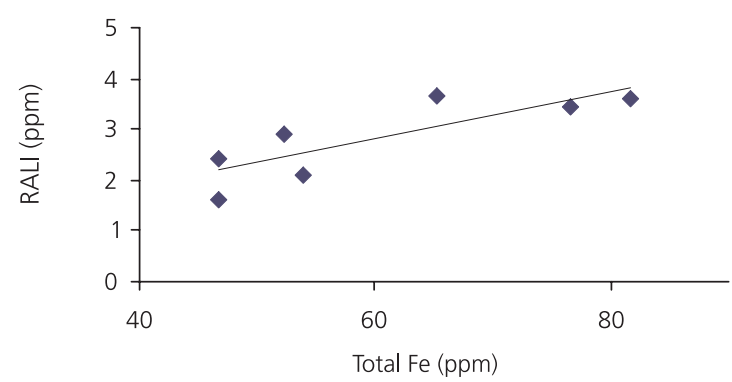

Artificial Gastric Juice $(R=0.983)$

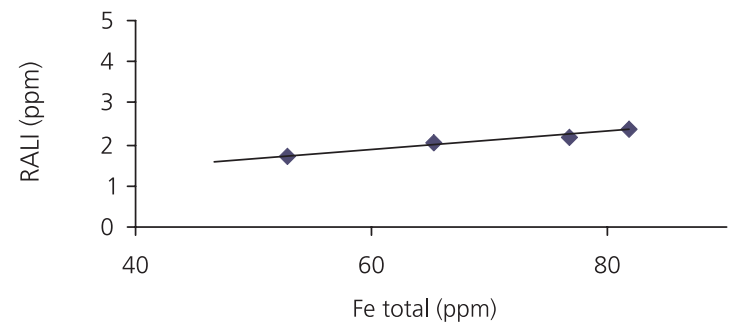

Artificial Saliva $(R=0.835)$

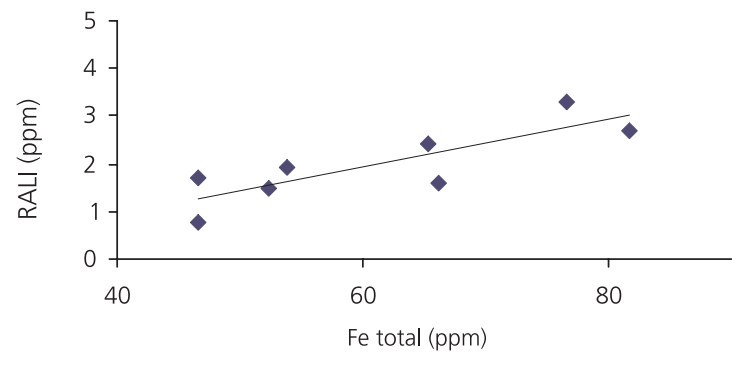

Water $(R=-0.180)$

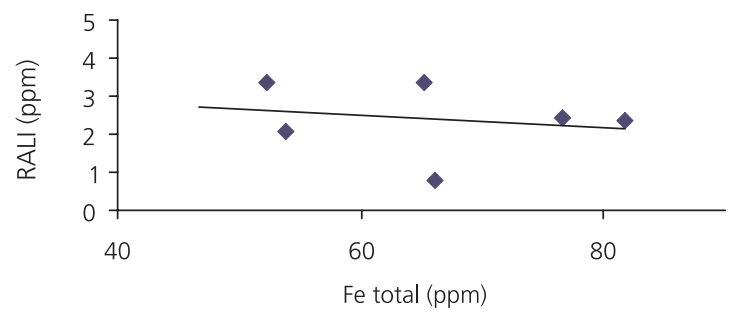

Figure 1. Correlation between total iron and redox-active labile iron (RALI) in fortified flours subjected to different extraction systems (values are taken from Table 1). Numbers in parenthesis show the correlation coefficients.

this information to the clinical evaluation of long-term exposure to dietary RALI in poorly nourished (with impaired antioxidant defenses), iron overloaded or atransferrinemic subjects deserves further investigation.

In conclusion, we found that the combined presence of iron and ascorbate favor the presence of RALI after extraction of iron-fortified flours, due to the redox activity of "free" (and not PA-bound) iron. A saline environment is required to accelerate $\mathrm{Fe}^{0}$ to $\mathrm{Fe}^{3+}$ solubilization. Our results and computer simulations indicate that the decomposition of an iron-PA complex is the probable source of RALI. There is a positive correlation between RALI and total iron in the biomimetic fluids, RALI representing ca. $1 \%-9 \%$ of the total iron.

\section{ACKNOWLEDGMENTS}

We thank Conselho Nacional de Desenvolvimento Científico e Tecnológico (CNPq) (process 506072/2004-5) and Fundação de Apoio à Pesquisa do Estado de São Paulo (FAPESP) (process 04/08305-6) for their sponsorship. Dr. Heraldo Possolo de Souza (Faculdade de Medicina - Universidade de São Paulo) kindly permitted the use of the microplate reader.

\section{REFERE NCES}

1. World Health Organization. Iron deficiency anaemia: assessment, prevention and control. A guide for programme managers (Document WHO/NHD/01.3); 2001. Available from: http://www. who.int/nutrition/publications/en/ida_assessment _prevention_control.pdf

2. Queiroz SS, Torres MA. Iron deficiency anemia in children. J Pediatr. 2000; 76(S3):S298-S304.

3. Miglioranza LHS, Matsuo T, Caballero-Cordoba GM, Dichi JB, Cyrino ES, Oliveira IBN, et al. Effect of long-term fortification of whey drink with ferrous bisglycinate on anemia prevalence in children and adolescents from deprived areas in Londrina, Paraná, Brazil. Nutrition. 2003; 19(5): 419-21.

4. Hurrell RF, Lynch S, Bothwell T, Cori H, Glahn R, Hertrampf $E$, et al. Enhancing the absorption of fortification iron - A SUSTAIN Task Force report. Int J Vit Nutr Res. 2004; 74(6):387-401. 
5. Brasil. Ministério da Saúde. Agência Nacional de Vigilância Sanitária (ANVISA). Resolução RDC $n^{\circ}$ 344, Dec 13, 2002.

6. Baltussen R, Knai C, Sharan M. Iron fortification and iron supplementation are cost-effective interventions to reduce iron deficiency in four subregions of the world. J Nutr. 2004; 134(10): 2678-84.

7. Brasil. Ministério da Saúde. Agência Nacional de Vigilância Sanitária (ANVISA) [cited 2001 Aug 3]. Available from: http://www.anvisa.gov.br/divulga/ noticias/030801.htm

8. Lynch SR. The impact of iron fortification on nutritional anaemia. Best Pract Res Clin Haematol. 2005; 18(2):333-46.

9. Esposito BP, Breuer W, Sirankapracha P, Pootrakul P, Hershko C, Cabantchik Zl. Labile plasma iron in iron overload: redox activity and susceptibility to chelation. Blood. 2003; 102(7):2670-7.

10. Esposito BP, Breuer W, Slotki I, Cabantchik ZI. Labile iron in parenteral iron formulations and its potential for generating plasma nontransferrin-bound iron in dialysis patients. Eur J Clin Invest. 2002; 32(S1):42-9.

11. Teucher B, Olivares M, Cori H. Enhancers of iron absorption: Ascorbic acid and other organic acids. Int J Vitamin Nutr Res. 2004; 74(6):403-19.

12. Jacobsen C, Timm M, Meyer AS. Oxidation in fish oil enriched mayonnaise: ascorbic acid and $\mathrm{pH}$ increase oxidative deterioration. J Agric Food Chem. 2001; 49(8):3947-56.

13. Almaas R, Rootwelt T, Oyasaeter S, Saugstad OD. Ascorbic acid enhances hydroxyl radical formation in iron-fortified infant cereal and infant formulas. Eur J Paediatr. 1997; 156(6):488-92.

14. Fisher AEO, Naughton DP. Iron supplements: the quick fix with long-term consequences. Nutr J. 2004; 3:2.

15. Carrier J, Aghdassi E, Platt I, Cullen J, Allard JP. Effect of oral iron supplementation on oxidative stress and colonic inflammation in rats with induced colitis. Alim Pharmacol Ther. 2001; 15(12): 1989-99.

16. Seril DN, Liao J, Ho KL, Warsi A, Yang CS, Yang GY. Dietary iron supplementation enhances DSS-induced colitis and associated colorectal carcinoma development in mice. Dig Dis Sci. 2002; 47(6):1266-78.

17. Carrier J, Aghdassi E, Cullen J, Allard JP. Iron supplementation increases disease activity and Vitamin E ameliorates the effect in rats with dextran sulfate sodium-induced colitis. J Nutr. 2002; 132(10):3146-50.
18. Troost FJ, Saris WHM, Haenen GRMM, Bast A, Brummer R-JM. New method to study oxidative damage and antioxidants in the human small bowel: effects of iron application. Am J Physiol Gastrointest Liver Physiol. 2003; 285(2):G354-9.

19. Chu MY, Beauchemin D. Simple method to assess the maximum bio-accessibility of elements from food using flow injection and inductively coupled plasma mass spectrometry. J Anal At Spectrom. 2004; 19(9):1213-6.

20. Esposito BP, Epsztejn S, Breuer W, Cabantchik ZI. A review of fluorescence methods for assessing labile iron in cells and biological fluids. Anal Biochem. 2002; 304(1):1-18.

21. Atkins $P$, Jones $L$. Chemical principles: the quest for insight. New York: W.H. Freeman. 1999.

22. Bothwell TH, MacPhail AP. The potential role of NaFeEDTA as an iron fortificant. Int J Vitamin Nutr Res. 2004; 74(6):421-34.

23. Poyner DR, Cooke F, Hanley MR, Reynolds DJM, Hawkins PT. Characterization of metal ion-induced $\mathrm{H}-3$ inositol hexakisphosphate binding to rat cerebellar membranes. J Biol Chem. 1993; 268(2): 1032-8.

24. Hurrell RF, Reddy MB, Burri J, Cook JD. An evaluation of EDTA compounds for iron fortification of cereal-based foods. Br J Nutr. 2000; 84(6):903-10.

25. Hurrell RF. Phytic acid degradation as a means of improving iron absorption. Int J Vitamin Nutr Res. 2004; 74(6):445-52.

26. Leenhardt F, Levrat-Verny MA, Chanliaud E, Remesy C. Moderate decrease of $\mathrm{pH}$ by sourdough fermentation is sufficient to reduce phytate content of whole wheat flour through endogenous phytase activity. J Agric Food Chem. 2005; 53(1):98-102.

27. Empson KL, Labuza TP, Graf E. Phytic acid as a food antioxidant. J Food Sci. 1991; 56(2):560-3.

28. Verweig W. CHEAQS PRO [computer program]. Version 2004.1: a program to calculate chemical equilibria in aqueous systems [cited 2006 May 15]. Available from: http://home.tiscali.nl/cheaqs/

29. Costello AJR, Glonek T, Myers TC. P-31 Nuclear Magnetic Resonance-pH titrations of myoinositol hexaphosphate. Carbohydr Res. 1976; 46(2): 159-71.

30. Kalinowski DS, Richardson, DR. The evolution of iron chelators for the treatment of iron overload disease and cancer. Pharmacol Rev. 2005; 57(4): 547-83.

Received on: 30/5/2006

Final version resubmitted on: 24/11/2006 Aproved on: 12/2/2007 